\title{
Political Protest and the Illinois Defense of Necessity
}

In 1961, the state of Illinois codified its criminal law and included a defense of necessity:

Conduct which would otherwise be an offense is justifiable by reason of necessity if the accused was without blame in occasioning or developing the situation and reasonably believed such conduct was necessary to avoid a public or private injury greater than the injury which might reasonably result from his own conduct. ${ }^{1}$

Recently, political protesters have successfully invoked this statute in defending against charges of trespass and disorderly conduct.

In early 1985, eight protesters entered the South African Consulate in Chicago and refused to leave unless the Consul General agreed to discuss apartheid with them. They were arrested on charges of criminal trespass. At trial, the defendants claimed to have believed that their illegal actions were necessary to prevent the greater evil of apartheid. ${ }^{2}$ In order to show the reasonableness of this belief, defendants called an array of distinguished witnesses to persuade the jury of the horrors of apartheid. After hearing testimony from the likes of Senator Paul Simon and Congressman Charles Hayes, the jury acquitted all eight defendants. ${ }^{3}$

Given the publicity surrounding several other successful political necessity defenses in Illinois ${ }^{4}$ and, more recently, Amy Carter's

${ }^{1}$ Criminal Code of 1961, Ill. Ann. Stat. ch. 38, § 7-13 (Smith-Hurd 1972) ("S.H.A.").

${ }^{2}$ City of Chicago v. Streeter, No. 85-108644 (Cook Cty., Ill., May 1985).

3 Andy Knott, 8 Acquitted of Trespass in Anti-Apartheid Protest, Chi. Tribune, $\$ 1$, p. 6, col. 1 (May 18, 1985).

- See People v. Brown, No. 78CM2522 (Lake Co., Ill., Feb. 1977), in which a group of protesters who had blocked the entrance to a nuclear power plant were charged with criminal trespass. Relying on the defense of necessity, they argued that they had not created the situation they had sought to correct and had reasonably believed their conduct was necessary to avoid the harm of a nuclear accident. Among the defense witnesses was a doctor who testified about the damaging effects of low-level radiation. The jury acquitted all of the defendants.

A similar result was reached in People v. Jarka, No. 002170 (Lake Cty., Ill., April 1985). The defendants were arrested when they blocked the entrance to the Great Lakes Naval Training Center in protest against United States naval operations in Central America and the Navy's role in the proliferation of nuclear weapons. They were charged with mob action. 
successful use of the defense against trespass and disorderly conduct charges in Massachusetts, ${ }^{\circ}$ it is likely that political protesters will continue to claim necessity both to avoid punishment and to gain publicity for their causes. Claims of political necessity may increase as defense attorneys become aware of recent articles explaining how to successfully invoke the necessity defense on behalf of political protesters. ${ }^{\circ}$

The necessity defense tends to appeal to a protester because it allows her "to educate the jury and judge about the subject of her protest." The defense is particularly attractive to a defendant in Illinois because the broad language of the state's statute requires only that the defendant reasonably believe his conduct is necessary in order to prevent a harm greater than that caused by his own behavior. The literal language of the statute, as with that of similarly broad statutes in other states, ${ }^{8}$ thus contrasts sharply with the far stricter requirements the common law imposed on defendants claiming necessity. ${ }^{\circ}$

This comment concludes, however, that the Illinois necessity defense should not be available in political protest cases. After briefly examining the necessity defense in general and "political

After a one-week trial on foreign policy and nuclear weapons, the jury found the defendants not guilty.

The necessity defense has been used in similar cases with the same result in jurisdictions other than Illinois. See People v. Lemnitzer, No. 27106E (Pleasanton-Livermore Jud'l Dist., Alameda Cty., Cal., 1982) (protest at nuclear research facility); State of Vermont v. Jeanne Keller, No. 1372-4-84 CnCr (Chittenden Cir. Dist. Ct., Nov. 1984) (demonstration against U.S. involvement in Central America); Commonwealth v. Berrigan, 472 A.2d 1099 (Pa. 1984) (damage to hydrogen bomb missile components).

s See Matthew L. Wald, Amy Carter Says Her Protest was Aimed at C.I.A. Crimes, N.Y. Times, $\S 1$, p. 13, col. 1 (April 14, 1987). Ms. Carter was arrested at a protest along with several others. The defendants characterized the trial as "the C.I.A. on trial." After hearing their testimony about the C.I.A.'s involvement in Central America, the jury acquitted all of the defendants. See Matthew L. Wald, Amy Carter Acquitted in Protest, N.Y. Times, $\$ 1$, p. 1, col. 5 (April 16, 1987).

- See Deborah Greenblatt, Defense of the Civilly Disobedient, 13 N.C. Central L. J. 158 (1982); William R. Durland, Conscience and the Law: A Court Guide for the Civilly Disobedient (1980); Robert Aldridge and Virginia Stark, Nuclear War, Citizen Intervention, and the Necessity Defense, 26 Santa Clara L. Rev. 299 (1986); and David E. Neely, Legal Necessity and Civil Disobedience: Preventing the Greater Harms of War and Apartheid, $74 \mathrm{Ill}$. Bar J. 596 (1986).

7 Greenblatt, 13 N.C. Central L. J. at 181 (cited in note 6). See also Neely, 74 Ill. Bar J. at 598 (cited in note 6).

s See, e.g., 16A Ky. Penal Code $§ 503.030$ (1985); 18 Pa. Consolidated Stats. § 503 (West 1983); 2 Tex. Penal Code Ann. $\$ 9.22$ (West 1974).

- See, e.g., United States v. Dorrell, 758 F.2d 427 (9th Cir. 1985); United States v. Kroncke, 459 F.2d 697 (8th Cir. 1972); Commonwealth v. Brugmann, 13 Mass.App.Ct. 373, 433 N.E.2d 457 (1982). 
necessity" claims in particular, the comment turns to the statutory defense in Illinois; surveying the statute's legislative history and judicial interpretations, the comment argues that courts should interpret "necessity" to incorporate the relatively stringent common law requirements, which virtually no political protester can satisfy. Finally, to bolster this interpretation, the comment offers several broad arguments that as a matter of policy, the necessity defense should not be available to justify trespass or disorderly conduct by political protesters. Even in the most difficult case, where the protest is against illegal conduct by the government or private persons, that conduct should be challenged by orderly means rather than lawbreaking.

\section{The Necessity Defense and "Political Necessity"}

Attempts to use the necessity defense in political protest cases are not new. The defense was often raised, for example, in cases arising out of protests against American military involvement in Vietnam. ${ }^{10}$ In virtually all of those cases, however, courts refused to permit the necessity defense. To understand why, it is useful to trace the evolution of the necessity defense in general.

\section{A. General Background on the Necessity Defense}

The defense of necessity-or "choice of evils"-justifies lawbreaking that is done in an effort to prevent a harm greater than the harm which the violated statute aims to prevent. ${ }^{11}$ The doctrine rests on the utilitarian premises that "the law ought to promote the achievement of higher values at the expense of lesser values" and that "sometimes the greater good for society will be accomplished by violating the literal language of the criminal law."12 But although these principles are easily stated, the proper scope of the necessity defense has provoked debate since earliest

10 United States v. Moylan, 417 F.2d 1002 (4th Cir. 1969); United States v. Cullen, 454 F.2d 386 (7th Cir. 1971); United States v. Turchick, 451 F.2d 333 (8th Cir. 1971); United States v. Beneke, 449 F.2d 1259 (8th Cir. 1971); United States v. Simpson, 460 F.2d 515 (9th Cir. 1972); Kroncke, 459 F.2d 697; United States v. Dougherty, 473 F.2d 1113 (D.C. Cir. 1973); United States v. Berrigan, 283 F.Supp. 336 (D. Md. 1968); State v. Marley, 54 Haw. 450, 509 P.2d 1095 (1973).

${ }^{11}$ For a general discussion of the necessity defense, see Wayne R. LaFave and Austin W. Scott, Jr., Criminal Law $\$ 50$ (1972).

12 Id. at 383 . Glanville Williams notes that the defense of necessity is an "assertion that conduct promotes some value higher than the value of literal compliance with the law." Glanville Williams, Criminal Law: The General Part § 229 at 722 (2d ed. 1961). 
common law times. ${ }^{13}$

Although the principle of necessity was recognized in the early common law, ${ }^{14}$ it was rarely invoked successfully. The English courts-like most courts today-were fearful that a broad necessity defense would too easily sanction departures from legality and encourage private determinations of law. Thus, they permitted the defense only when the harm the illegal act was to prevent was imminent-for example, pulling down a house to prevent a fire from spreading ${ }^{15}$ - and they laid down the emphatic rule, in Regina $v$. Dudley and Stephens, that the defense of necessity could not justify murder. ${ }^{16}$

In the United States, two principles of the necessity doctrine developed quite early that later would become central to the question of whether the doctrine could be used in political protest cases. First, a defendant needed only "reasonable grounds of belief" in the necessity of her illegal conduct in order to sustain a defense of necessity. ${ }^{17}$ Second, the question of necessity was for the jury, not the judge, unless the evidence was completely inadequate. ${ }^{18}$

${ }^{13}$ For a thorough discussion of the defense in early English law, see Edward B. Arnolds and Norman F. Garland, The Defense of Necessity in Criminal Law: The Right to Choose the Lesser Evil, 65 J. Crim. L. \& Criminology 289 (1974). See also Williams, Criminal Law $\S 231$ at 724 (cited in note 12).

14 See Arnolds and Garland, 65 J. Crim. L. \& Criminology at 291 (cited in note 13).

1s Williams, Criminal Law $\$ 231$ at 725 (cited in note 12).

16 Regina v. Dudley and Stephens, 14 Q.B.D. 273 (1884) (murder and cannibalism not justified by prospect of starving at sea). For an interesting discussion of invoking the necessity defense to justify murder, see Lon Fuller, The Case of Speluncean Explorers, 62 Harv. L. Rev. 616 (1949).

17 In United States v. Ashton, 24 F.Cas. 873 (C.C.D. Mass. 1834), the court held that mutiny by the crew of a ship was justified because the crew had a "bonafide reasonable belief" that the ship was unseaworthy. The court made clear that actual peril was not a requirement of the defense but that "reasonable grounds of belief, that the ship was unseaworthy" would be enough to successfully invoke the defense. Id. at 874 .

1* This principle was announced in the famous Brisbee Deportation Case, State v. Wooton, Crim. No. 2065 (Cochise Cty., Ariz., Sept. 13, 1919), discussed in Comment, The Law of Necessity as Applied in the Brisbee Deportation Case, 3 Ariz. L. Rev. 264 (1963). See also Arnolds and Garland, 65 J. Crim. L. \& Criminology at 792-94 (cited in note 13). In Wooton, a member of a posse formed to round up members of a group that had called a strike of copper miners was charged with kidnapping. He asserted the defense of necessity and offered to prove that the strikers were trying to obstruct the war, had stored up a large amount of ammunition, and had threatened citizens; that help from federal troops had been sought to no avail; and that the group's leader had told the sheriff he could no longer control his men. The judge ruled that the weight and sufficiency of the evidence of necessity were for the jury and that a judge could exclude evidence of necessity only if the evidence were completely inadequate or could in no way establish a defense of necessity. The jury heard the evidence, deliberated fifteen minutes, and returned a verdict of "not guilty" on the first ballot. 


\section{B. The Modern Common Law Standard}

More recently, American courts have adopted four rather strict requirements at common law for even presenting a necessity defense to the jury. These rules reflect a reluctance easily to allow claims of necessity. Because these requirements apply under federal law and operate to bar virtually all pleas of political necessity when federal law is applicable, ${ }^{19}$ protesters are anxious to have their cases tried in state court.

The common law requires that: 1) the harm to be avoided is greater than the harm caused by the defendant's.illegal activities; 2) there is no legal alternative to breaking the law; 3) the harm to be prevented is imminent; and 4) it is reasonable to believe the defendant's actions will be effective in abating the harm. ${ }^{20}$ These factors are discussed below.

1. Balance of harms. The demand that the harm avoided outweigh the harm caused simply reflects the utilitarian premises that constitute much of the foundation for the necessity doctrine. It is important to note that the harm to be averted that counts in this calculus is the harm averted by this one instance of lawbreaking, and not from other, similar instances of illegal conduct.

2. No legal alternative. In United States v. Bailey, ${ }^{21}$ the defendants, convicts who escaped from from a federal prison, sought to justify their flight by arguing the necessity defense; they claimed

The Brisbee Deportation Case is troubling because it seems to allow a majority to inflict its will on an unpopular minority group as long as it can convince a jury of its peers that such action was necessary. "The criminal law exists to protect individuals from those who would violate their personal and property rights, and the willingness of the community to excuse conduct directed at a racial, ethnic, or political minority is a real concern." J. Thomas Sullivan, The Defense of Necessity in Texas: Legislative Invention Come of Age, 16 Houston L. Rev. 333, 363 (1979).

${ }_{19}$ There is currently no codified federal defense of necessity, nor does the proposed Federal Criminal Code contain such a defense. The Commissioners concluded that "even the best statutory formulation [of the necessity defense] is a source of unwarranted difficulty." 1 Working Papers of the National Commission on Reform of Federal Common Laws 261,270 (1968).

${ }^{20}$ These rules are well articulated in Marley, 509 P.2d at 1095, which involved a protest against Honeywell Corporation's involvement in the Vietnam war. See also Brugmann, 433 N.E.2d at 461 , in which the court phrased the requirements as follows:

[I]t is apparent that the application of the [necessity] defense is limited to the following circumstances: (1) the defendant is faced with a clear and imminent danger, not one which is debatable or speculative; (2) the defendant can reasonably expect that his action will be effective as the direct cause of abating the danger; (3) there is no legal alternative which will be effective in abating the danger; and (4) the Legislature has not acted to preclude the defense by a clear and deliberate choice regarding the values at issue.

${ }^{21} 444$ U.S. 394 (1980). 
that prison guards and inmates had physically abused them. The Supreme Court rejected this claim, holding that the necessity defense must fail "if there was a reasonable, legal alternative to violating the law, 'a chance both to refuse to do the criminal act and also to avoid the threatened harm." "22

The requirement stated in Bailey demands that those claiming the defense investigate other, legal opportunities before engaging in illegal conduct. If those legal alternatives would accomplish the same goal as the illegal conduct, the necessity defense will not be allowed.

3. Imminence. The third common law requirement is that the harm to be avoided must be imminent. This requirement is closely related to the "no legal alternatives" requirement. LaFave and Scott write:

It is sometimes said that the defense of necessity does not apply except in an emergency-when the threatened harm is immediate, the threatened disaster imminent. Perhaps this is but a way of saying that, until the time comes when the threatened harm is immediate, there are generally options open to the defendant, to avoid the harm, other than the option of disobeying the literal terms of the law. ${ }^{23}$

As the same commentators point out, "just how 'immediate' the threatened harm must be poses a difficult issue."24 Often it turns on the precise facts of the case, or on the attitude of the court. In People $v$. Richards ${ }^{26}$ for example, the defendant escaped from prison after he learned that other inmates were planning to kill him; a California appeals court held that the defense was unavailable because the defendant had not shown that his life was in danger on the very afternoon of the escape. A more liberal approach is exemplified by People $v$. Harmon, ${ }^{26}$ where a prisoner escaped after he was threatened with assault but before any such assault was impending. The Michigan Supreme Court ruled that the necessity defense should go to the jury, holding that imminence is "to be decided by the trier of fact taking into consideration all the surrounding circumstances, including defendant's opportunity and ability to avoid the feared harm."27

\footnotetext{
22 Id. at 410 , quoting LaFave and Scott, Criminal Law $\$ 49$ at 379 (cited in note 11).

${ }^{23}$ LaFave and Scott, Criminal Law $\S 49$ at 388 (footnote omitted) (cited in note 11).

24 Id. § 49 at 379 n. 40 .

2s 269 Cal.App.2d 768, 75 Cal.Rptr. 597 (1969).

2853 Mich.App. 482, 220 N.W.2d 212 (1974).

27220 N.W.2d at 214 . A New Hampshire court took the same approach some time ago
} 
4. Nexus between defendant's actions and prevention of the harm. Finally, the common law requires that it must be reasonable to believe that the defendant's actions will be effective in abating the danger of harm. In United States $v$. Simpson, the Ninth Circuit articulated the requirement: "An essential element of the socalled justification defense is that a direct causal relationship be reasonably anticipated to exist between defendant's action and the avoidance of the harm." No Note that this requirement ensures that the utilitarian calculus recognized by the necessity defense will not be used as a pretext for engaging in illegal conduct for its own sake.

It is worth emphasizing that the common law requires that all four requirements be satisfied independently. ${ }^{29}$ A strong showing on one part of the test will not compensate for a failure to satisfy another part. Thus, for example, a protester could not get the defense to the jury if his acts of protests were futile, no matter how grave the harm he was trying to avoid.

\section{The Common Law Requirements and their Philosophical Foundations}

One might wonder why the common law has so narrowed the set of circumstances in which a criminal defendant may invoke necessity as a defense: why, if the harm that the defendant seeks to avert through his illegal conduct exceeds the harm the conduct causes, must the conduct meet any other standard? One way of understanding this reluctance to allow the defense is through through a consideration of the utilitarian principles that underlie the defense.

in Aldrich v. Wright, 53 N.H. 398, 401-03 (1873):

The term "imminent" does not describe the proximity of the danger by any rule of mechanical measurement. . . The law does not fix the distance of time between the justifiable defense and the mischief, for all cases, by the clock or calendar. The chronological part of the doctrine of defense, like the rest of it, is a matter of reasonableness; and reasonableness depends upon circumstances.

${ }^{28} 460$ F.2d 515, 518 (9th Cir. 1972). The court did not believe that the defendant's destruction of draft cards at his local office of the Selective Service System could have been effective in alleviating the harm from the Vietnam war. In a similar case, the Ninth Circuit again denied a defendant a necessity defense because his act of spray-painting government property could not reasonably have been expected to lead to a termination of the missile program. See Dorrell, 758 F.2d 427. See also Arnolds and Garland, 65 J. Crim. L. \& Criminology at 300 n.127 (cited in note 13). But consider Aldridge and Stark, 26 Santa Clara L. Rev. at 333 (cited in note 6) (suggesting that acts to prevent nuclear proliferation, "no matter how futile they may seem, should be weighed by the jury").

${ }^{29}$ See, e.g., Brugmann, 433 N.E.2d at 461. 
The requirement that the harm the illegal act seeks to avoid exceed the harm the act causes reflects what is usually known as "act utilitarianism"- the doctrine that evaluates each individual human action according to the extent to which it increases or decreases human happiness. ${ }^{30}$ The final common law requirement, that the illegal act be reasonably likely to avoid the greater harm, likewise follows fairly directly from the principle of act utilitarianism.

The other two requirements-that the harm to be averted be imminent and that no legal alternative be available-place stiffer constraints on defendants pleading necessity. These elements introduce a presumption against illegal acts even when they are likely to prevent more harm than they cause and add a different sort of reasoning to the utilitarian calculus. To put it another way, they exemplify "rule utilitarianism," usually defined as the principle that a general rule of conduct, binding in individual cases, should be chosen according to the extent to which following it will increase or decrease happiness. ${ }^{31}$ The judgment is that the value of having a "rule of thumb" outweighs, on the whole, the value that might be gained from disobeying the rule in individual cases, both because of uncertainty as to whether a disobedient act really is better and because of the costs of engaging in such a calculation before every act. The chaos that would eventually result if each person made private determinations of law justifies a strong presumption in favor of obeying the commonly accepted law, even if in some individual cases the private determination might produce a better result. ${ }^{32}$ The stringent requirements against claiming necessity also reflect a strong presumption against resorting to force rather than consent in order to achieve public goals, even where the harm from force in a particular case might be dwarfed by the possible harm that force seeks to prevent. $^{33}$

${ }^{30}$ See Jeremy Bentham, Introduction to the Principles of Morals and Legislation (Hafner Lib. ed. 1948).

31 For the first modern statement of rule utilitarianism, see R. F. Harrod, Utilitarianism Revised, 45 Mind 137 (April 1936), reprinted in Samuel Gorovitz, ed., Mill's Utilitarianism with Critical Essays 73 (1971). On the distinction between the two varieties of utilitarianism, see David Lyons, Forms and Limits of Utilitarianism 2-17 (1965). For a brief criticism of the distinction, see J. J. C. Smart, Outline of a Theory of Utilitarian Ethics, in J. J. C. Smart and Bernard Williams, eds., Utilitarianism: For And Against 9-10 (1973).

${ }^{32}$ The basic question a rule utilitarian asks is, "What would happen if everyone did X?" See Lyons, Forms and Limits at 11-15 (cited in note 31 ). On the value of "rules of thumb" over individual consideration, see Smart and Williams, Utilitarianism at 42-43, 125 26 (cited in note 31 ).

${ }^{33}$ See part IV-A (notes 73-79 and accompanying text). 
These principles help to explain the common law's reluctance to recognize a defense of necessity whenever a person's isolated acts have been undertaken to prevent a greater evil. As we shall see, they also offer important insights into the folly of recognizing a political necessity defense.

\section{The Defense of Necessity in Illinois}

Although this background is helpful in understanding the bases of the necessity doctrine, the question of its proper scope in Illinois is to a large extent a matter of statutory construction. And although the plain language of the statute may be seen as covering "political necessity" claims as well, a simple invocation of the "plain language" rule will not suffice where (as this comment argues) both the common law background and policy considerations call for a more limited scope. ${ }^{34}$ The comment therefore investigates the statute further, turning first to the legislative materials and then to case law.

\section{A. Statutory Materials}

The legislative history of the Illinois Criminal Code does not indicate whether the legislature intended to change the common law defense of necessity. Nor do other sections of the Code provide guidance, even a section entitled "Applicability of Common Law."3s However, the comments of the drafters of the Proposed Code are relatively persuasive indications of legislative intent here. When the General Assembly enacted the Criminal Code, it adopted practically the exact language of the drafters' Proposed Code. None of the few, small changes affected the necessity provision..$^{36}$

The comments of the drafters suggest that they intended for

s4 Consider Train v. Colorado Pub. Int. Research Group, 426 U.S. 1, 10 (1976) ("When aid to construction of the meaning of words, as used in the statute, is available, there certainly can be no 'rule of law' which forbids its use, however clear the words may appear on 'superficial exmination.' "); Midlantic Nat. v. New Jersey Dept., 106 S.Ct. 755, 759-60 (1986) ("The normal rule of statutory construction is that if Congress intends for legislation to change the interpretation of a judicially created concept, it makes that intent specific.").

${ }^{36}$ S.H.A. § 1-3 (1962). The relevant statutory language provides:

No conduct constitutes an offense unless it is described as an offense in this Code or in another statute of this State. However, this provision does not affect the power of a court to punish for contempt or to employ any sanction authorized by law for the enforcement of an order, civil judgement, or decree.

${ }^{36}$ See 1 House J. Ill. 1417-20 (May 17, 1961); 2 House J. Ill. 3224 (June 29, 1961) (House's amendment accepted by the Senate). For a synopsis of the legislative action on the Code, see H.B. 342, in Final 1961 Legislative Synopsis and Digest. 
common law interpretations to continue to assist in judicial decision making:

However, the supersession of all common-law definitions of particular offenses does not mean that the large mass of interpretative rules developed under the common law is superseded; these rules are a highly valuable part of our criminal law, and their effective replacement by statutory law would be exceedingly difficult. ${ }^{37}$

In addition, the comments concerning the necessity provision in particular reveal that the drafters did not wish to restrict the common law defense. ${ }^{38}$ This, of course, does not prove that they did not intend the broad statutory language to expand the defense. Yet in related areas, the Illinois courts have held that broad language must be interpreted narrowly in light of restrictive common law rules. For example, one court used a common law requirement to narrow the statutory defense of compulsion, a defense closely related to necessity. ${ }^{38}$ The court held that the compulsion defense was limited by the common law rule "that one ought himself to die rather that escape through the murder of an innocent."40

\section{B. Illinois Case Law}

Few Illinois cases deal with the necessity defense; often, where the defense is raised, the state does not prosecute. ${ }^{41}$ While the Illinois Supreme Court has not yet faced the issue, several Illinois appellate courts have considered claims of necessity raised by political protesters. By utilizing common law requirements, these decisions have refused to allow political protesters to plead necessity.

People v. Krizka, ${ }^{42}$ for example, involved anti-abortion activists who were convicted of criminal trespass for their protests at an abortion clinic. On appeal, they claimed that they had acted out of necessity and that the killing of fetuses was a greater harm than

3738 S.H.A. § 1-3, Committee Comments (1961).

so See id. (agreeing with the drafters of the Model Penal Code ("MPC") that the Wisconsin statute was flawed in that it restricted the common law necessity defense) (see Wis. Code art. 939.47 (1956); MPC \& 3.02, Comment 2 (Tent. Draft. No. 8., 1958)).

39 See S.H.A. ch. 38, § 7-11 (1962).

10 People v. Gleckler, 82 Ill.2d 145, 411 N.E.2d 849, 854 (1980).

¿ For a discussion of the relationship between the necessity defense and prosecutorial discretion, see Arnolds and Garland, 65 J. Crim. \& Criminology at 298-301 (cited in note 13).

42 Ill.App.3d 288, 416 N.E.2d 36, 37 (1980). 
was criminal trespass to land. The court refused to let the jury hear evidence about the abortion issue, on the ground that "other optional courses of action" had been available to the protesters. ${ }^{43}$ The court also rejected the claim that the defendants were acting to prevent a greater harm, "because the 'injury' prevented by the acts of criminal trespass is not a legally recognizable injury." 44 The court noted that the Supreme Court had held in Roe v. Wade that a state may not "unduly burden the abortion decision during the first trimester of pregnancy." And if the state may not limit the decision to abort, the court reasoned, a protester may not invoke a state's laws to protect himself from the consequences of having done so.

Another case involving anti-abortion activists, People $v$. Stiso ${ }^{47}$ expressly adopted Krizka's line of reasoning and barred evidence concerning the harms from abortion. In distinguishing City of Chicago $v$. Mayer, ${ }^{48}$ where the jury was allowed to hear evidence on necessity, the Stiso court said:

The crucial distinction between that case and the case at bar is that the injury to be avoided in Mayer, aggravation of a spinal injury, was not protected by law. Here the very thing which defendants allegedly sought to prevent through their actions, abortion of fetuses, has been given the legal protection we have described. ${ }^{40}$

${ }^{43}$ Id. The "other alternatives" rule in Illinois stems from People v. White, 78 Ill.App.3d 979, 397 N.E.2d 426 (1979), in which the defendant escaped from prison, he claimed, because he heard reports that his wife had been raped and his daughter attacked. The court refused the necessity defense because the correctional center where the defendant was held had a procedure for emergency leave. 397 N.E.2d at 1247, citing LaFave and Scott, Criminal Law $\$ 49$ at $387-88$ (cited in note 11 ). Note also that it is not clear what harm the defendant had hoped to prevent; even if the rumors were true he was faced with a fait accompli-it was too late for him to do anything.

See also People v. Perez, 97 Ill.App.3d 278, 422 N.E.2d 945 (1981). Charged with unlawful use of weapons within five years of conviction of another felony, the defendant claimed that it was necessary for him to carry a weapon because members of a rival gang had tried to kill him. The court denied the necessity defense in light of the reasonable alternative to carrying a weapon-avoiding contact with threatening gang members.

$\$$ Krizka, 416 N.E.2d at 37. For an article advocating precisely this approach in abortion protest cases see Note, Necessity as a Defense to a Charge of Criminal Trespass in an Abortion Clinic, 48 Cincinnati L. Rev. 501 (1979).

4510 U.S. 113 (1973).

46 Krizka, 416 N.E.2d at 37, citing Planned Parenthood of Central Missouri v. Danforth, 428 U.S. 52 (1976).

6793 Ill.App.3d 101, 416 N.E.2d 1209, 1211 (1981).

48 56 Ill. $2 \mathrm{~d} 366,308$ N.E.2d 601 (1974). See the description of Mayer in note 50 below.

49416 N.E.2d at 1212. 
Illinois courts also have had occasion to interpret the necessity defense outside the context of political protest. The leading case from the Illinois Supreme Court is People v. Unger, ${ }^{50}$ in which a jury convicted the defendant of escaping from prison. On appeal, he testified that his escape was necessary because of sexual assaults and threats on his life. The appellate court reversed the conviction, and the Illinois Supreme Court sustained that reversal, holding that the trial judge's refusal to give an instruction on necessity was erroneous. The Unger court essentially followed the guidelines for escape cases laid down in the California case of People v. Lovercamp: ${ }^{51}$

(1) The prisoner is faced with a specific threat of death, forcible sexual attack or substantial bodily injury in the immediate future;

(2) There is no time for a complaint to the authorities or there exists a history of futile complaints which make any result from such complaints illusory;

(3) There is no time or opportunity to resort to the courts;

(4) There is no evidence of force or violence used towards prison personnel or other innocent persons in the escape; and

(5) The prisoner immediately reports to the proper authorities when he has attained a position of safety from the immediate threat. ${ }^{52}$

These conditions cannot be found in the language of the Illi-

so 66 Ill.2d 366, 362 N.E.2d 319 (1977). Only three other Illinois Supreme Court cases address the issue. In City of Chicago v. Mayer, 56 Ill.2d 366, 308 N.E.2d 601 (1974), a medical student tried to prevent police from moving an injured man without a stretcher; the court held, without explanation, that Mayer was entitled to an instruction on the necessity defense. Although the court did not mention it, the harm in Mayer appeared to be imminent. In People v. Ballard, 59 Ill.2d 580, 322 N.E.2d 473, 475 (1975), the court held that the defendant's "vague impression that someone might get hurt" did not establish a defense of necessity to the charge of possessing a firearm without having a state firearm owner's license. And in People v. Lucus, 91 Ill.2d 370, 243 N.E.2d 288 (1968), the court held that in order for a defendant to be entitled to a jury instruction on the necessity defense, "he has the responsibility to insure that the instruction tendered is in proper form."

${ }^{31} 43$ Cal.App.3d 823, 118 Cal.Rptr. 110, 115 (1974). The defendants in Lovercamp sought to prove that they had been subjected to continuing threats of homosexual assault by other inmates, that prison officials had not responded to the threats, and that on the day of the escape there had been a fight between the defendants and the other inmates. 118 Cal.Rptr. at 116.

${ }^{32}$ For a discussion of the necessity defense in the escape context, see Martin R. Gardner, The Defense of Necessity and the Right to Escape from Prison-A Step Towards Incarceration Free From Sexual Assault, 49 So. Cal. L. Rev. 110 (1975); Comment, Necessity 
nois statute; instead, they clearly track the four common law factors identified earlier. The requirements that no innocent person be harmed, that the prisoner be threatened with bodily injury, and that the prisoner turn himself in as soon as possible, ensure that the harm avoided will outweigh the harm caused. The Lovercamp test also demands that the harm be imminent. And in emphasizing "a history of futile complaints which make any result from such complaints illusory," the standard seems to require that there be no legal alternative to the escape. Finally, the nature of such cases means that the act of escape can be reasonably expected to avert assault in each case, since the harm to be avoided occurs inside the prison and not outside of it.

It is not clear, however, to what extent the Illinois Supreme Court in Unger accepted the common law rules as a matter of law. The court endorsed the Lovercamp conditions, but it interpreted the Illinois Code not to require that each of them be met in order for the defense to go to the jury. In Unger, the defendant had not immediately turned himself in to the authorities and therefore failed to satisfy the fifth requirement, but the court held that this was not determinative and that the jury should have been instructed on necessity. The court treated the Lovercamp guidelines as jury matters affecting the weight and credibility of the evidence. $^{\text {s3 }}$

Nevertheless, there are indications that the court in Unger assumed that the Illinois necessity defense requires at least some form of imminence. First, one of the defendant's own proffered jury instructions used the words "imminent infliction of death or great bodily harm." Second, the lower court opinion that the Supreme Court affirmed held that while a "gun to the head immediacy" was not essential to establish necessity, there must be specific threats of death, forcible sexual attack, or serious bodily harm in the immediate future. ${ }^{55}$ Finally, in the recent case of People $v$. Whitson, the court clearly interpreted Unger as requiring imminence, among other things-it rejected a necessity claim on the ground that the defendant "was not in imminent danger of bodily harm." "Bs

Defined: A New Role in the Criminal Defense System, 29 U.C.L.A. L. Rev. 409, 425-27 (1981); Sullivan, 16 Houston L. Rev. at 350 (cited in note 18).

ss 362 N.E.2d at 323.

54 Id. at 321.

ss People v. Unger, 33 Ill.App.3d 770, 338 N.E.2d 442, 446 (1975) (emphasis added).

so 127 Ill.App.3d 999, 470 N.E.2d 1054, 1058 (1984). 
In a way, it is not surprising that the Illinois courts have read the common law requirements of imminence, no legal alternative, and a reasonable nexus into the broadly worded statutory defense of necessity. One can fairly easily tease these requirements from the language of the statute, which requires that the actor "reasonably believed [his] conduct was necessary." Arguably, unless the harm were about to happen it would not be necessary to break the law-there would be time to try and find other means of preventing the evil. ${ }^{57}$ And if other means to prevent the harm exist, the conduct cannot fairly be said to be "necessary." Finally, if there is little hope that the challenged conduct will avert the greater evil, it stretches ordinary language to say that the conduct is "necessary" to prevent the evil.

\section{The Common Law Requirements and Political Protest}

Thus, in interpreting the the language of the Illinois statute, the Illinois courts have turned to the common law requirements. Application of these standards in political protest cases would virtually always bar protesters from using the defense.

\section{A. Balancing the Harms}

In any case where a protest is registered against a legally sanctioned activity, such as abortion or the production of nuclear power, the balance of harms must weigh against the protester. This is because the harm the protester seeks to prevent cannot be recognized as a harm at all. ${ }^{58}$ The issue has already been decided by the people, through the Constitution or by acts of representative, legislative bodies. In a society based on democratic decision ma'ing, this is how values are ranked-a protester cannot simply assert that her view of what is best should trump the decision of the majority of elected representatives. The necessity defense must fail as a matter of law for protesters in such situations.

The situation is more complicated when the protest aims at illegal action by the government or private persons. Here, protests arguably act to regain popular control of public officials or of private persons seeking to evade popular mandates. Indeed, in some cases the immediate harm from protesters' illegal actions is clearly outweighed by the harm from the illegality the protesters seek to stop. For example, the harm from the illegal and hazardous dump-

${ }^{57}$ See LaFave and Scott, Criminal Law $\S 49$ at 379 (cited in note 11).

${ }^{68}$ Stiso, 416 N.E.2d at 1212. 
ing of chemical wastes in a residential area might far outweigh the harm from a brief trespass by a small group of protesters.

Nevertheless, this does not prove that a protester should be able to break the law merely because he can establish that the illegal acts he protests are worse than his own. The other requirements of the common law foreclose such a conclusion. As the final section of this comment will describe, these other requirements rest on important policies which demand that even illegal action be challenged through legal rather than illegal channels.

\section{B. No Legal Alternatives}

Application of the requirement that a defendant claiming necessity have had no legal alternative will effectively bar a necessity defense in any political protest case. This is because a protester virtually always could have tried a legal form of protest that also would have attracted publicity for her cause. But although this limitation has been applied in cases ranging from trespass at nuclear plants to destruction of draft cards, ${ }^{59}$ few courts have explicitly discussed what constitutes an available "legal alternative."

Commentators supporting the political necessity defense argue that the "no legal alternative" requirement should be relaxed to require that "no reasonable traditional alternatives are available to stop or prevent the harm, or a history of futile attempts to use accepted means makes any anticipated results from such means illusory."

Even though American democracy was founded in 1776 upon the principle that all political power is inherent in the people, and that government derives its just powers from the consent of the governed, in 1986-in the nuclear age-these principles hardly conform to reality. ... A Assuming that other options are always open to people in a democracy assumes that the democracy is pure, which can only be true in theory. A free flow of information rarely exists, and alternative democratic

${ }^{69}$ See, e.g., United States v. Richardson, 588 F.2d 1235 (9th Cir. 1978), in which the defendants were convicted of conspiracy to possess and distribute laetrile. On appeal, the court rejected defendants' argument that the laetrile was needed to help cancer patients, because there were optional courses of action available such as challenging the law or producing laetrile in the United States. The Eighth Circuit applied the same rule in Kroncke, 459 F.2d 697.

to Aldridge and Stark, 26 Santa Clara L. Rev. at 333 (cited in note 6) (original emphasis). 
processes do not always work. ${ }^{61}$

Such skepticism about perfect information and pure democracy has, of course, some foundation in fact. But it does not follow that a person should be allowed to break the law just because his efforts to use traditional democratic channels do not always work. Inevitably, in a democracy-even a "perfect" one-some lobbying efforts will not "work" because the majority will reject them. Democratic principles do not promise that all ideas will prevail; they promise only that the ideas that do prevail, do so because a majority of representatives has endorsed them. In the absence of factors suggesting discrimination or other systematic defects in the representative process, the products of that process should be respected. That, of course, is the teaching of Carolene Products and the substantial jurisprudence stemming from its famous footnote. ${ }^{62}$ If anything, the challenge to Carolene Products today is from those who stress that in a society of diffuse majorities, a small but concentrated pressure group may have an influence far out of proportion to its size. ${ }^{63}$ Protest groups should not be able to argue, then, that their failure to succeed in the democratic process should permit them to circumvent it.

\section{Imminence}

Commentators supporting the political necessity defense also argue for a relaxation of the traditional requirement of imminence. For example, Aldridge and Stark argue that the imminence requirement should be liberally construed as to protests against nuclear weapons because preventing nuclear war is "a long process which begins early in the process leading to the harm."64 And David Neely argues that "under Illinois law defendants can engage in long-term planning to decide which illegal course would be more effective in abating the evils sought to be prevented."65

Nevertheless, the common law's imminence requirement generally has been construed strictly to deny the defense to protesters who are not acting to prevent a harm that is about to occur. ${ }^{6 B}$ And

o1 Id. at 337-338.

${ }^{2}$ United States v. Carolene Products, 304 U.S. 144, 152 n.4 (1938); see also John Hart Ely, Democracy and Distrust: A Theory of Judicial Review (1980). (1985).

os See Bruce A. Ackerman, Beyond Carolene Products, 98 Harv. L. Rev. 713, 722-28

of Aldridge and Stark, 26 Santa Clara L. Rev. at 331 (cited in note 6).

${ }^{65}$ Neely, 74 Ill. Bar J. at 597 (cited in note 6).

${ }^{68}$ See cases cited in note 10. 
"imminence" loses any meaning if, as Neely urges, it can be extended to include any amount of time required for long-term planning. Like the requirement of "no legal alternatives," the imminence requirement creates an important presumption in favor of legal means of opposition, a policy that will be examined in greater detail in the final part of this comment.

\section{Nexus between Illegal Activity and the Prevention of Harm}

The requirement that the illegal activity be reasonably calculated to prevent the harm also may prove to be an insurmountable barrier for protesters pleading necessity. The formidability of this barrier depends on how effective the protester's activity must be.

On the one hand, protests alone virtually never alter fundamental government policy: ${ }^{67}$ burning draft cards would not have stopped the war in Indochina, for example, and destroying one nuclear warhead will not avert a full-scale nuclear war. On the other hand, protests may make an important contribution to changing policy when other strong forces are pushing for change-as our Vietnam experience also shows. And as commentators have pointed out, this effect can be magnified if, for instance, the protester is a respected person in the community. ${ }^{68}$

Nevertheless, a single protest should not be justified on a showing that widespread civil disobedience on the whole could reasonably be expected to prevent the harm. ${ }^{60}$ Virtually any act of trespass would be justified under that approach, even one that is highly nonbeneficial in isolation. Thus the "reasonable nexus" requirement should be vigorously enforced to require that the particular protest in question be reasonably likely to prevent the harm by itself. Strict interpretation of this requirement would keep the necessity doctrine relatively close to the cases of direct, immediate, individual physical harm in which it evolved. ${ }^{70}$ It would also bar use of the defense in nearly every protest situation, for in these it is nearly always a complex mix of factors (and not protests

${ }^{67}$ The recent protests in South Korea may be an exception.

${ }^{68}$ Arnolds and Garland, 65 J. Crim. L. \& Criminology at $300 \mathrm{n} .127$ (cited in note 13) (noting that "Daniel Ellsberg's releasing of the Pentagon Papers arguably, at least, had a significant effect on the war"). Ellsberg, a respected researcher at the Rand Institute, later said he was prompted to release the papers by protests against the war.

${ }^{69}$ For a contrary view, consider Aldridge and Stark, 26 Santa Clara L. Rev. at 345 (cited in note 6).

${ }^{70}$ In Dudley and Stephens, for example, consider the small number of individuals and their isolation from other factors that might have complicated the question of whether it was "necessary" to kill to survive. 
alone) that affect policy. ${ }^{71}$ This result is justified by compelling policies: maintaining public order and channeling disputes into proper legal and political channels. It is to these policies that the comment now turns.

\section{Policies Underlying Strict Limits on Necessity Pleas}

It is not enough, of course, simply to insist that the traditional common law limits on the necessity defense be faithfully observed. The Illinois statutory language (like many others ${ }^{22}$ ) is broad enough to permit the courts to continue to develop, and perhaps expand, the defense in common law fashion.

This comment argues, however, that the necessity defense should be strictly construed, and denied to political protesters, as a matter of public policy as well. The political necessity defense implicates some of the most basic postulates of the American system: that the nation should be governed by laws, not men, and that those laws should be made through representatives chosen by the majority. Allowing liberal use of the necessity defense to justify protesters' trespasses is in considerable tension with these fundamental premises.

Commitment to public order and to majority rule entails rejecting a claim of political necessity even when there is a colorable argument that a protester's trespass is far less serious than the harm she is seeking to prevent. In this way, our system is ruleutilitarian, rather than act-utilitarian, as described earlier. The overall benefits of maintaining order and resolving disputes through majority rule, not direct action, outweigh the occasional harm that might result. This section explores these arguments in greater detail.

\section{A. The Necessity Defense and Public Order}

The use of the necessity defense in political protest cases exonerates public disorder. It allows individuals to make private determinations of the law in accordance with their own subjective

${ }^{71}$ For the contrary view, see Neely, $74 \mathrm{Ill}$. Bar J. at 598 (cited at note 6), arguing that the protest involved in Streeter had an effect on American policy toward South Africa. It is doubtful that this proposition could be proved, and even more doubtful that the protest had a significant effect.

A more severe act of protest (for example, blowing up a nuclear weapons production facility) would be more effective, but the harm it caused would obviously be much greater too.

72 See statutes cited in note 8. 
views of what is best. The courts have refused to permit this result and thus have denied protesters the defense. In United States $v$. Berrigan, for example, the defendants burned draft records and then pleaded necessity as a defense to charges of destroying government property and interfering with the draft. The trial court condemned the protesters' efforts to avoid the legal consequences of their conduct, noting that "[i]t is axiomatic that chaos would exist if an individual were permitted to impose his beliefs upon others and invoke justification in a court to excuse his transgression of a duly enacted law."73

The same concern for upholding the authority of laws, even potentially unconstitutional ones, underlies the Supreme Court's decision in Walker $v$. City of Birmingham, ${ }^{74}$ upholding the conviction for criminal contempt of Martin Luther King and other civil rights protesters, based on their violation of an injunction against marching in the city. The Court held that the defendants were obligated to obey the injunction even assuming, as was eventually held, ${ }^{75}$ that it was unconstitutional. In upholding the traditional "collateral bar" rule, the majority insisted that defendants must attempt to have an injunction modified or dissolved in court before disobeying it, rather than precipitate disorder by flouting an injunction. The Court distinguished picketing and marching from "pure speech" and added:

Civil liberties, as guaranteed by the Constitution, imply the existence of an organized society maintaining public order without which liberty itself would be lost in the excesses of unrestrained abuses. ... [Regulations on picketing] ha[ve] never been regarded as inconsistent with civil liberties but rather as one of the means of safeguarding the good order on which they ultimately depend. ${ }^{78}$

On appeal in the Berrigan case, the Fourth Circuit in United States $v$. Moylan followed the same reasoning as Walker, rejecting the protesters' claims that they were entitled to acquittal because they believed the Vietnam War was wrong. The court said:

No legal system could long survive if it gave every individual

23 F.Supp. 336, 339 (D. Md. 1968) (emphasis added).

24388 U.S. 307 (1967).

78 The Court later struck down the ordinance involved in Walker on the ground that its overbreadth violated the first amendment. See Shuttlesworth v. Birmingham, 394 U.S. 147 (1969).

76388 U.S. at 316 , quoting Cox v. New Hampshire, 312 U.S. 569, 574 (1941). 
the option of disregarding with impunity any law which by his personal standard was judged morally untenable. Toleration of such conduct would not be democratic, as appellants claim, but inevitably anarchic. ${ }^{77}$

The passages in Walker and Moylan strike to the heart of the matter: whatever limits the demands of public order may place on political action in an individual case, these demands are ultimately justified as general rules because they secure a host of benefits-including protecting the ability of individuals to take effective political action in the first place. Political protests are of little value when the protesters can be shouted down, or worse. The same laws that protect the property on which the protester seeks to trespass also protect the protester herself, her person, family, or property, from those who would use physical force to silence her ${ }^{78}$ It is sensible and fair to forbid protesters to flout the very laws whose protection they would invoke. ${ }^{79}$

In sanctioning public disorder, the political necessity defense also upsets the delicate balance that courts seek to achieve under the first amendment between, on the one hand, freedom of speech of protesters and on the other, the property interests of individuals and the regulatory interests of government. The first amendment provides substantial protection against prosecutions for trespassing in public forums and on private property of a public character, ${ }^{80}$ but it offers far less of a shield when the speaker enters onto private property or onto public property where security interests are greater (such as prisons and military bases). ${ }^{81}$ The claims of necessity cut across and blur this distinction-indeed, protesters are most likely to turn to the necessity defense in cases where they

77417 F.2d at 1009.

78 See Walker, 388 U.S. at 316 , quoting Cox, 312 U.S. at 574.

79 A further potential difficulty is that necessity, if established, is likely to be treated as a justification for the act, not merely an excuse. Contrast Williams, Criminal Law at 745 (cited in note 12) (noting that necessity is traditionally treated as a justification), with Glanville Williams, The Theory of Excuses, 1982 Crim. L. Rev. 732, and George P. Fletcher, Rethinking Criminal Law 552-68, 575-80 (1978) (both arguing that necessity should be treated as an excuse). A finding that the defendant's action is justified imposes a corollary duty on others not to interfere with it. See Williams, Criminal Law at 745 . Not only would the protesters go free, but those who sought to stop their trespass would themselves face legal sanctions.

${ }^{80}$ See, e.g., Hague v. CIO, 307 U.S. 495, 515 (1939) (Roberts, concurring); Cox v. Louisiana, 379 U.S. 559, 578 (1965) (Black, concurring and dissenting); Amalgamated Food Employees Union v. Logan Valley Plaza, 391 U.S. 308 (1968).

81 See, e.g., Adderley v. Florida, 385 U.S. 39 (1966) (prison); Greer v. Spock, 424 U.S. 828 (1976) (military base). 
clearly have no first amendment right. ${ }^{82}$

Instead of weighing the interests, the necessity analysis focuses heavily on the content, indeed the "correctness," of the protesters' speech: Are the protesters right to warn of the harm as they do? Is the harm so great as to justify their trespass? Are they correct that it is imminent? First amendment jurisprudence has developed rules strongly to discourage judges and juries from evaluating the merits of the speech in question; ${ }^{83}$ yet the necessity defense turns the spotlight on precisely that issue.

\section{B. Circumvention of the Democratic Process}

The aim of protesters in political necessity cases is to gain a judicial forum in which to argue their cause. Indeed, defense counsel for protesters at abortion clinics who plead necessity admit that their aim is to get the abortion issue back before the United States Supreme Court. ${ }^{84}$ Thus protesters use valuable and increasingly scarce court resources to debate basic policy decisions. ${ }^{85}$ The necessity defense runs afoul of another deep structural principle in American government: that such decisions should be made by popularly elected representatives, not by judges or juries or individuals. ${ }^{86}$

In a great many protest cases-including those involving South Africa, abortion, and nuclear weapons-protesters are simply questioning the wisdom of basic choices that have been made by the appropriate decision makers (whether it is the Supreme Court on the constitutional right to abortion or the Congress and executive on foreign policy). Unless one postulates some "higher" unwritten law, the protesters are simply asserting that they disagree with the decision of the proper authority.

Again, however, the situation is more complicated when protesters assert that the government or a private person is violat-

s2 That is, in cases where the protesters have gone beyond speech and have trespassed or instigated violence.

${ }^{83}$ See Lee C. Bollinger, The Tolerant Society 88 (1986) (discussing "fortress" model of protecting speech against infringements likely to result from review in individual cases); Geoffrey R. Stone, Content Regulation and the First Amendment, $25 \mathrm{Wm}$. \& Mary L. Rev. 189 (1983).

B4 See Jane Seaberry, Protesters Barred at Abortion Clinic, Wash. Post § B, p. 1, col. 6.(Feb. 25, 1978).

ss The trial in Streeter, for example, lasted over a week though the charge was a simple one of trespass. See Knott, Chi. Trib. $\S 1$, p. 6, col. 1 (cited in note 3).

${ }^{80}$ See John Hart Ely, The Supreme Court, 1977 Term-Foreword: On Discovering Fundamental Values, 92 Harv. L. Rev. 5, 17 (1978) ("It would not be an acceptable proposition [to anyone] that appointed judges should run the country."). 
ing the law. Here the protesters' claims not only seek to avert an event recognized as a "harm" by the common law standard, but they also reinforce the democratic process rather than undercutting it-the protest is aimed at holding the governmental or private actor accountable to the rules laid down by the policymaking bodies.

Nevertheless, protesters should not be able to invoke the necessity defense even where they aim to prevent illegal conduct. Instead, they must challenge the action in court in an orderly fashion, seeking equitable relief: a declaratory judgment and an injunction. In this posture, with no independent controversy created from an illegal trespass, the courts can perform their proper role of determining whether the challenged action violates the law.

Of course, in many cases such a challenge will not be possible. In areas involving foreign or military affairs or complex, discretionary policy judgments, the courts may refuse to address the issue because it is a political question or is committed to agency discretion. ${ }^{87}$ Moreover, a single protester or group of protesters may lack standing to challenge the action because they have suffered no "particularized injury," but are merely asserting a "generalized grievance" common to the entire citizenry. ${ }^{88}$

That these barriers exist, however, does not prove that protesters should be allowed to turn to the necessity defense to circumvent them. Instead, they constitute another strong reason for denying the defense. Justiciability doctrines reflect a deep concern that in a democratic society, certain sorts of determinations should be left to the accountable branches: ${ }^{89}$ in particular, those determina-

${ }^{87}$ On political questions, see, e.g., Baker v. Carr, 369 U.S. 186, 211-13, 217 (1962) (discussing foreign relations issues as political questions; issues lacking judicially manageable standards); Luftig v. McNamara, 373 F.2d 664, 666 (D.C. Cir. 1967) (decision to fight in Vietnam committed to political branches).

On issues left to agency discretion, see 5 U.S.C. $\S 701(a)(2)(1982)$ (agency action unreviewable where "committed to agency discretion by law"); Heckler v. Chaney, 470 U.S. 821 , 830 (1985) ("[R]eview is not to be had if the statute is so drawn so that a court would have no meaningful standards against which to judge the agency's exercise of discretion.").

ss See, e.g., Schlesinger v. Reservists to Stop the War, 418 U.S. 208, 217 (1974) (rejecting claim that congressmen's service in military reserve was unconstitutional, on ground that "that claimed nonobservance . . . would adversely affect only the generalized interest. of all citizens in constitutional governance"); Frothingham v. Mellon, 262 U.S. 447, 588 (plaintiff must show "that he has sustained or is immediately in danger of sustaining some direct injury as the result of its enforcement, and not merely that he suffers in some indefinite way in common with people generally").

so Warth v. Seldin, 422 U.S. 490, 498 (1975) (standing limits reflect "concern about the proper-and properly limited-role of the courts in a democratic society"); Vander Jagt v. O'Neill, 699 F.2d 1166, 1178-79 (D.C. Cir. 1983) (Bork, concurring) (justiciability doctrines 
tions that are either highly specialized and discretionary or that are so broad and fundamental as to affect the populace as a whole. Standing rules, for example, are based in part on the concern that the federal courts not become "publicly funded forums for the ventilation of public grievances"; they also serve to ensure that the legal issues "will be resolved, not in the rarified atmosphere of a debating society, but in a concrete factual context conducive to a realistic appreciation of the consequnces of judicial action."90

Allowing the political necessity defense undercuts all of these goals. As noted, in many cases-for example, cases challenging policies towards South Africa and nuclear weapons-the issues the protesters seek to litigate are committed to other branches. ${ }^{91}$ In nearly all cases of political necessity, the protesters are seeking to air a "generalized grievance." And because the protesters themselves are seldom injured in any particularized way by the alleged illegality, they raise the issue of legality in its most abstract form. If the protesters' challenge would be nonjusticiable as a declaratory action, it should not become justiciable from the posture of a necessity plea. Indeed, protesters who trespass or obstruct a facility and then claim necessity are manufacturing litigation..$^{92}$

Nor is the problem alleviated when the ultimate decision maker is the jury. Despite the arguments of some commentators, ${ }^{93}$ juries should not make policy any more than courts should. ${ }^{94} \mathrm{Ju}$ rors are likewise unelected and lacking in policymaking expertise: indeed, jury selection probably ensures that the jurors sitting are as unfamiliar with the issue as possible. ${ }^{95}$ Moreover, jurors are rep-

based on concern "about the constitutional and prudential limits to the powers of an unelected, unrepresentative judiciary in our kind of government").

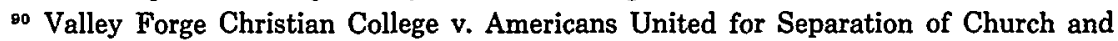
State, 454 U.S. $464,473,472$ (1981).

92 Luftig, 373 F.2d at 666 .

${ }^{82}$ Feigned litigation is likewise foreclosed under article III. United States v. Johnson, 319 U.S. 302 (1943) (collusive suit).

${ }_{93}$ "In a democracy, a jury of one's peers . . . is the proper body to determine if reasonable alternatives exist." Aldridge and Stark, 26 Santa Clara L. Rev. at 334 (cited in note 6).

94 Consider U.S. v. Best, 476 F.Supp. 34, 41 (D. Colo. 1979) ("no jury will decide on the correctness vel non of any act of Congress or the executive branch"). This view has the support of the American Law Institute. See MPC $\$ 3.02(1)$ (c) and comment 2 (Tent. Draft $8,1952)$.

${ }^{85}$ Most states allow a challenge for cause if a juror has a "unique" interest in the subject matter, Walter E. Jordan, Jury Selection $\$ 4.08$ at 54 (3d ed. 1980), and peremptory challenges are often further used to ensure that knowledgeable jurors will be excluded. In complex civil cases, several courts have denied requests for jury trials on the ground that a jury could not comprehend the issues. See Comment, Complex Civil Litigation and the Seventh Amendment Right to a Jury Trial, 51 U. Chi. L. Rev. 581, 582-83 nn. 11-12 (1984). 
resentative of the community only in a very limited sense: large segments of the community are excluded either by being excused from service altogether or by being dismissed on peremptory challenges or for cause.

\section{Necessity and Civil Disobedience}

Even if the political necessity defense is in tension with certain fundamental American values, it might be argued that political protest has likewise played an important part in the nation's development and that some recognition of political necessity is necessary and appropriate to maintain the conditions in which such protests can flourish and be effective. The civil rights movement, particularly as led by Martin Luther King Jr., provides perhaps the greatest support for this argument. Nonetheless, in an important way the necessity defense is inappropriate, and even counterproductive, to the use of organized protest as a means of influencing policy.

The civil rights movement as led by Dr. King practiced, with great effectiveness, the strategy of civil disobedience. As taught and practiced by Dr. King, and earlier by Mahatma Gandhi, civil disobedience aims to demonstrate the flawed nature of society's judgment by submitting to that judgment. Gandhi's statement to the English judge when he was convicted of sedition in 1922 best explains this idea:

Nonviolence implies voluntary submission to the penalty for noncooperation with evil. I am here, therefore, to invite and submit cheerfully to the highest penalty that can be inflicted upon me for what in law is a deliberate crime and what appears to me to be the highest duty of a citizen. The only course open to you, the judge, is either to resign your post, and thus disassociate yourself from evil if you feel that the law you are called upon to administer is an evil and that in reality I am innocent, or to inflict on me the severest penalty if you believe that the system and the law you are assisting to administer are good for the people of the country and that my activity is therefore injurious to the public weal. ${ }^{96}$

In a similar vein, Henry David Thoreau spent the night in jail for refusing to pay a poll tax to a government that allowed slavery,

o8 Mahatma Gandhi, A Plea for the Severest Penalty Upon Conviction of Sedition (1922), reprinted in Louis Blom-Cooper, ed., The Law as Literature 95, 100-01 (1961). 
and he was annoyed that the very next morning "some one interfered, and paid that tax," thus allowing him to be released. ${ }^{97}$ And Dr. King wrote in his "Letter from Birmingham Jail" that "an individual who breaks a law that conscience tells him is unjust, and willingly accepts that penalty by staying in jail to arouse the conscience of the community over its injustices, is in reality expressing the very highest respect for the law."

The necessity defense has no role to play in a strategy of civil disobedience. The point of civil disobedience is to force a society to recognize the contradiction of using a system of justice to defend an unjust institution. If the person practicing civil disobedience is set free not because the offensive institution has been removed but because the system of justice has made an exception, then the contradiction remains hidden, and the object of the protest is lost.

Of course, civil disobedience in this form is not the only sort of political protest. And it is unrealistic to assume that all protesters will remain undeterred by the prospect of prosecution. Nevertheless, in an important sense the use of the necessity defense not only conflicts with a commitment to order and majority rule, but also robs the protest itself of some of its demonstrative power.

\section{Conclusion}

The Illinois defense of necessity should not be available to political protesters. The illegal acts of political protesters may be based on the sincerest of motives, but as the Fourth Circuit has pointed out, "it implies no disparagement of their idealism to say that society will not tolerate the means they chose to register their opposition." Al Allowing the defense for political protesters is inconsistent with the Illinois Code, the common law, and established doctrines of constitutional law and American political philosophy. Individuals and juries should not be left to decide case by case whether the law should be followed, or broken for some higher goal.

Brent D. Wride 1980).

${ }^{97}$ Henry David Thoreau, On the Duty of Civil Disobedience 235 (New Amer. Lib. ed.

${ }^{88}$ Martin Luther King, Letter from Birmingham City Jail 8 (1963). King was likewise angry when bail was paid for him after his arrest at a protest in Albany, Georgia; the payment apparently was made by town leaders precisely to defuse the atmosphere and reduce King's influence. See David L. Garrow, Bearing the Cross: Dr. Martin Luther King, Jr. and the Southern Christian Leadership Conference (1986).

92 Moylan, 417 F.2d at 1009. 